\title{
Seasonal Photosynthesis and Carbon Assimilation of Dynamics in a Zelkova serrata (Thunb.) Makino Plantation
}

\author{
Chung-I Chen ${ }^{1}\left(0\right.$, , Ya-Nan Wang ${ }^{2}$, Heng-Hsun Lin ${ }^{3}$, Ching-Wen Wang ${ }^{4}{ }^{\oplus}$, Jui-Chu Yu ${ }^{3}$ and Yung-Chih Chen ${ }^{1,3, *}$ \\ 1 Department of Forestry, National Chung Hsing University, No. 145, Xingda Rd., Taichung 40227, Taiwan; \\ rk.aee@msa.hinet.net \\ 2 School of Forestry and Resource Conservation, College of Bio-Resources and Agriculture, National Taiwan \\ University, No. 1, Sec. 4, Roosevelt Rd., Taipei 10617, Taiwan; m627@ntu.edu.tw \\ 3 The Experimental Forest, College of Bioresources and Agricultural, National Taiwan University, No. 12, Sec. 1, \\ Qianshan Rd., Zhushan Township, Nantou County 55750, Taiwan; a7107192001@yahoo.com.tw (H.-H.L.); \\ nicky3369@gmail.com (J.-C.Y.) \\ 4 Endemic Species Research Institute, No. 1, Minsheng E. Rd., Jiji Township, Nantou County 55244, Taiwan; \\ kilorsoul@gmail.com \\ * Correspondence: chih320@gmail.com; Tel.: +886-492-612-210
}

Citation: Chen, C.-I.; Wang, Y.-N.; Lin, H.-H.; Wang, C.-W.; Yu, J.-C.;

Chen, Y.-C. Seasonal Photosynthesis and Carbon Assimilation of Dynamics in a Zelkova serrata (Thunb.) Makino Plantation. Forests 2021, 12, 467. https://doi.org/10.3390/ f12040467

Academic Editor: Zdeněk Vacek

Received: 12 March 2021

Accepted: 9 April 2021

Published: 11 April 2021

Publisher's Note: MDPI stays neutral with regard to jurisdictional claims in published maps and institutional affiliations.

Copyright: (c) 2021 by the authors. Licensee MDPI, Basel, Switzerland. This article is an open access article distributed under the terms and conditions of the Creative Commons Attribution (CC BY) license (https:// creativecommons.org/licenses/by/ $4.0 /)$.

\begin{abstract}
As anthropogenic greenhouse gas emissions intensify global climate change, plantations have become an important tool to mitigate atmospheric $\mathrm{CO}_{2}$. Our aim in this study was to estimate carbon assimilation and clarify the impact of environmental factors on the photosynthesis of Zelkova serrata (Thunb.) Makino, an important plantation species that is extensively planted in low altitude regions of East Asia. We measured monthly gas exchange parameters and leaf area index to estimate carbon assimilation. The results showed that gas exchange was significantly affected by vapor pressure deficit and temperature, especially in the dry season, and both photosynthetic rate and carbon assimilation decreased. Lower daytime assimilation and higher nighttime respiration during the dry season, which caused a $43 \%$ decrease in carbon assimilation in Z. serrata plantations. Z. serrata exhibited lower photosynthetic rate and lower carbon assimilation following planting in a tropical monsoon climate area. Therefore, the effects of extreme weather such as high temperature and vapor pressure deficit on Z. serrata forest carbon budget could be stronger in the future. Leaf area showed seasonal variation, and severe defoliation was caused by a typhoon in the summer. The annual carbon assimilation was estimated at $3.50 \mathrm{MgC} \mathrm{ha}^{-1}$ year $^{-1}$ in the study area.
\end{abstract}

Keywords: canopy; leaf area index; photosynthetic rate; vapor pressure deficit; water deficit

\section{Introduction}

Forests are the world's largest terrestrial carbon sink and can sequester $\mathrm{CO}_{2}$ from the atmosphere, modify atmospheric components, mitigate greenhouse effects, and provide ecosystem services such as provisioning of fodder and timber and non-timber products that facilitate sustainable livelihoods. Therefore, a profound understanding of forest carbon budgets under extreme weather conditions is required urgently [1,2]. However, plantations are subject to various environmental stresses in the field that may impact their photosynthetic efficiency, growth performance, and carbon sequestration potential [3,4]. For example, environmental factors such as precipitation and soil water content may not be the major factors affecting carbon assimilation, whereas vapor pressure deficit and warming could strongly impact forest carbon sinks under drought conditions $[5,6]$.

Seasonality drives cycles of plant productivity in several ecosystems, and seasonal variation of photosynthesis and respiration are essential for ecosystem-atmosphere $\mathrm{CO}_{2}$ exchange $[7,8]$. For example, photosynthetic light-use efficiency peaks in spring and then declines due to leaf aging or water stress, and night respiration gradually decreases during the growing season [7]. The impact of extreme weather on forests is becoming increasingly 
severe under climate change, especially in seasonally dry ecosystems, due to cycles of prolonged drought and heavy rain. Drought is the primary cause of stress in forest ecosystems under climate change and may increase tree mortality under climatic warming [6]. In 2011, an intense drought impacted several regions around the world, causing a reduction in forest carbon sequestration [9]. Drought during the early growth season has long-lasting effects on photosynthesis and ecosystem carbon balance in plantations [3]. Severe drought suppressed tree photosynthesis more than respiration, leading to a reduction of $0.23-0.53 \mathrm{Pg}$ of carbon in the Amazon Basin, turning the forest from a carbon sink to a source within a short period [10]. Drought usually accompanies high temperature and vapor pressure deficit, which influence forest carbon balance. For example, increasing vapor pressure deficit under climatic warming can reduce forest $\mathrm{CO}_{2}$ uptake regardless of changes in soil water content, therefore warming may be the main climate factor that impacts carbon storage in tropical dry region $[5,6]$. Consequently, the influences of environmental factors on forest carbon balance require detailed multisite investigation [10]. Additionally, the forest response to changing environmental conditions may affect the regional and global climate [6].

Determining plantation species that are adapted to regional environmental conditions is necessary because of both limited plantation areas and climate change. In this study, we measured photosynthesis-related parameters to estimate the carbon assimilation of Zelkova serrata (Thunb.) Makino, an important plantation species in East Asia with high woody carbon content and economical value. Z. serrata mainly grows in the river valleys and sparse forest habitats beside streams, preferring fertile, moisture-laden, and well-drained soil conditions [11,12]. In addition, it exhibits considerable variation in growth performance under different growth site environments. Temperature seasonality, annual precipitation, annual mean temperature, and precipitation of the warmest quarter have been reported to be the key factors influencing its natural distribution in China [11]. The aims of the present study were to clarify the seasonal dynamic on photosynthesis and carbon assimilation dynamics of $Z$. serrata plantations and identify the key environmental factors influencing its growth performance under tropical monsoon climates.

\section{Materials and Methods}

\subsection{Study Site and Species}

The data for this study were collected in 2011 at Wan-Long Farm, a lowland former sugarcane plantation owned by the Taiwan Sugar Corporation in Sinpi Township, Pingtung, Taiwan $\left(120^{\circ} 36^{\prime} 30^{\prime \prime}\right.$ E, $22^{\circ} 31^{\prime} 26^{\prime \prime} \mathrm{N}, 69 \mathrm{~m}$ above sea level). The soils are classified as Entisols with more than $60 \%$ sandstone parent material and $45 \%-55 \%$ gravel content, and the soil profile is shallow $(<40 \mathrm{~cm}$ depth) $[12,13]$. In the study site, 14 species were used for afforestation from 2002 to 2005, with Z. serrata widely planted near the center of the farm in 2003. Z. serrata is a pioneer species frequently used in lowland afforestation, with the second largest plantation area in Taiwan. The initial stand density was 1500 seedlings ha ${ }^{-1}$ $(2.5 \times 2.5 \mathrm{~m}$ tree spacing), with constant pruning and weed removal. Mean diameter at breast height was calculated in a $20 \times 25 \mathrm{~m}$ area in 2010, which was $3.89 \pm 1.58 \mathrm{~cm}(N=27)$. Mean tree height was $3.46 \pm 1.28 \mathrm{~m}(\mathrm{~N}=27)$. The surrounding area of the study plot had the same species and similar size, which had $77.4 \%$ of crown density on average.

Microclimate data were collected at a microclimate station $400 \mathrm{~m}$ southeast of experimental plot from 2009 to 2011, which had a rain gauge and a temperature and relative humidity probe (HMP45C, Vaisala, Finland). The region has a typical tropical monsoon climate, with a high frequency of typhoons and afternoon thundershowers during summer. However, the annual precipitation in 2011 was the lowest $(1929 \mathrm{~mm})$ during the study period and represented an intense drought event. In 2011, the January and June mean air temperature were 16.6 and $28.0^{\circ} \mathrm{C}$, respectively; annual precipitation was concentrated from May to September (wet season). The monthly precipitation, soil water content, and average maximum temperature variation in 2011 are shown in Figure 1. Data on soil water content were collected by the microclimate station using a time-domain reflectometer 
(TDR, CS616, Campbell Scientific Inc., Logan, UT, USA) installed $20 \mathrm{~cm}$ underground, and showed a pattern similar to that of precipitation, being the lowest in March $(8.8 \%)$ and the highest in July (19.4\%) in 2011.

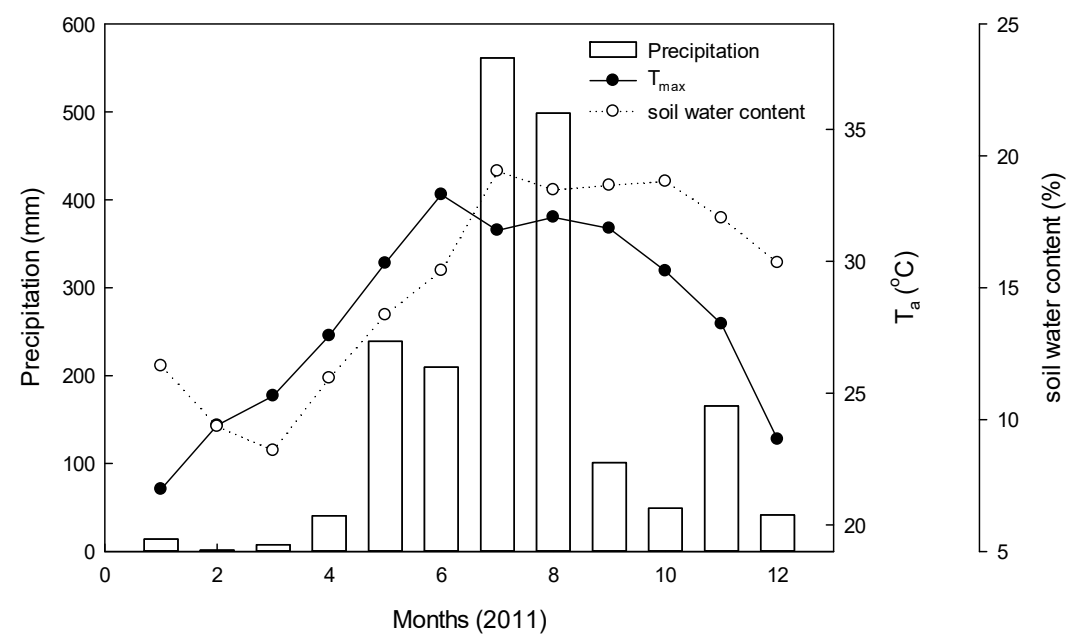

Figure 1. The monthly average maximum temperature $\left(\mathrm{T}_{\max }\right)$, soil water content, and accumulated precipitation in 2011.

\subsection{Measurements of Gas Exchange and Leaf Area}

The crowns of shade-intolerant species, such as Z. serrata, are usually mono-level of canopies, which is indicated by an leaf area index (LAI) $=1.07$, and monthly variation in the 0.4-2.1 range in 2011. To enable convenient transportation of instruments, we selected three nearby trees for gas exchange measurements. Scaffolds ( $1.7 \mathrm{~m}$ height) were set near the sample trees with tripods so the leaf clamp reached the canopy leaves. Diurnal variations in leaf gas exchange were measured using portable photosynthesis systems (LI-6400; LI-COR, Lincoln, NE, USA) with a clear chamber top (LI-6400-08; LI-COR) one day per month for each sample tree in 2011 from three intact, fully expanded mature leaves on the same side of the canopy. The 5-7th leaf from the top was selected for measurement to prevent sampling juvenile and aging leaves. The sampled leaves were fully placed in the $2 \times 3 \mathrm{~cm}$ leaf chamber of the instrument. Measurements were taken hourly from 8:00 a.m. to 4:00 p.m. (mean solar time), and net photosynthesis rate $\left(\mathrm{P}_{\mathrm{n}}\right)$, stomatal conductance $\left(\mathrm{g}_{\mathrm{s}}\right)$, transpiration rate $(\mathrm{E})$, and intercellular $\mathrm{CO}_{2}$ concentration $\left(\mathrm{C}_{\mathrm{i}}\right)$ were recorded. The flow rate was set to $500 \mu \mathrm{mol} \mathrm{s}{ }^{-1}$ and the air inlet of the LI-6400 was connected to a plastic tube (2-3 m in length), with the end set away from the operator to prevent the influence of human activities, and the $\mathrm{CO}_{2}$ concentration in the leaf chamber was maintained at the level of the ambient atmosphere. The $\mathrm{CO}_{2}$ sample concentrations ranged from 382.4 to $395.9 \mathrm{ppm}$ during max photosynthesis in summer. The air temperature $\left(T_{a}\right)$, leaf temperature $\left(T_{1}\right)$, vapor pressure deficit $\left(\operatorname{VPD}_{a}\right)$, and leaf vapor pressure deficit $\left(\mathrm{VPD}_{1}\right)$ were also recorded. We represented four days of diurnal data in January 28, May 31, September 4, and November 25 from monthly measurements in 2011. Photosynthetic photon flux density (PPFD) and VPD were measured on the leaves. The data gap in September 4 was caused by rain in the afternoon.

The photosynthesis response to different light intensity gradients was measured to construct photosynthetic light response curves. Measurements were taken for three leaves per sampled tree in each season using an LI-6400 with an artificial LED light chamber (LI6400-02B; LI-COR). The leaf selection criteria were the same for the diurnal measurement. Sample leaves were exposed to $500 \mu \mathrm{mol} \mathrm{m}{ }^{-2} \mathrm{~s}^{-1}$ artificial PPFD for a few minutes before measurements were taken to induce leaf stomatal opening. The artificial light intensities were set at $0,5,10,20,50,100,200,500,750,1000,1500$, and $2000 \mu \mathrm{mol} \mathrm{m}^{-2} \mathrm{~s}^{-1}$ in sequence with about 10-20 min of stabilization time under each light intensity. Seasonal measurements of photosynthetic light response curves were used to calculate maximum assimilation rate $\left(\mathrm{A}_{\max }\right)$ and shape parameter $(\theta)$. Simultaneously, quantum efficiency $(\alpha)$ 
and dark respiration rate $\left(\mathrm{R}_{\mathrm{d}}\right)$ were calculated from the initial slope of the photosynthetic light response curve, at light intensities lower than $50 \mu \mathrm{mol} \mathrm{m}^{-2} \mathrm{~s}^{-1}[14,15]$.

Tree total leaf area was estimated from the LAI, measured monthly at dusk from the top and under the canopy in three sample trees $[15,16]$. LAI was measured using a plant canopy analyzer (LAI-2200; LI-COR) in four directions under each sample tree. The sensor was covered with a lens cap $\left(90^{\circ}\right.$ opening) to prevent overestimation of the canopy leaf area owing to shading by the main branch and trunk. The total leaf area of each sample tree was calculated as LAI multiplying canopy projected area of an individual tree's canopy. The canopy projected area was calculated as an ellipse area following measurement of the major and minor axis in two perpendicular directions as crown projection.

\subsection{Data Processing and Analysis}

According to several studies, the light response curve can demonstrate the effects of environmental factors such as nutrient levels, temperature, and water variables on leaf photosynthesis [16-18]. Therefore, the leaf carbon assimilation $\left(\mathrm{A}, \mu \mathrm{mol} \mathrm{m}^{-2} \mathrm{~s}^{-1}\right)$ was calculated from the following equation:

$$
\mathrm{A}\left(\mathrm{A}_{\max }, I_{l}\right)=\mathrm{A}_{\max } \frac{2 \alpha I_{l} / \mathrm{A}_{\max }}{1+\frac{\alpha I_{l}}{\mathrm{~A}_{\max }}+\sqrt{\left(1+\frac{\alpha I_{l}}{\mathrm{~A}_{\max }}\right)^{2}-4 \theta \frac{\alpha I_{l}}{\mathrm{~A}_{\max }}}}
$$

where $A_{\max }\left(\mu \mathrm{mol} \mathrm{m} \mathrm{m}^{-2} \mathrm{~s}^{-1}\right.$ ) is the maximum net assimilation of $\mathrm{CO}_{2}, \alpha$ is the quantum efficiency, $\mathrm{I}_{1}\left(\mu \mathrm{mol} \mathrm{m}{ }^{-2} \mathrm{~s}^{-1}\right)$ represents leaf-level light intensity, which is derived from the measurements at the canopy top according to Beer's Law, and $\theta$ is the shape parameter of the photosynthetic light response curve, calculated as the slope of the tangent at the light saturation point. The associated parameters are listed in Table 1. The model has been well-tested and extensively applied in several leaf carbon assimilation studies $[14,16-18]$. In addition, the model is used as upscaling from leave to canopy level estimation by considering the light extinction in canopy.

Table 1. Average values ( \pm standard error) of quantum efficiency $(\alpha)$, shape parameter $(\theta)$, maximum net assimilation rate $\left(\mathrm{A}_{\max }\right)$, and dark respiration rate $\left(\mathrm{R}_{\mathrm{d}}\right)$ of Zelkova serrata (Thunb.) Makino across different seasons.

\begin{tabular}{ccccc}
\hline & Winter & Spring & Summer & Autumn \\
\hline$\alpha\left(\mathrm{mol} \cdot \mathrm{mol}^{-1}\right)$ & $0.038 \pm 0.007$ & $0.041 \pm 0.001$ & $0.036 \pm 0.006$ & $0.032 \pm 0.008$ \\
$\theta$ & $0.004 \pm 0.001$ & $0.005 \pm 0.001$ & $0.005 \pm 0.001$ & $0.006 \pm 0.002$ \\
$\mathrm{~A}_{\max }\left(\mu \mathrm{mol} \mathrm{m}^{-2} \mathrm{~s}^{-1}\right)$ & $0.92 \pm 0.43$ & $3.01 \pm 0.78$ & $4.99 \pm 1.21$ & $5.57 \pm 1.94$ \\
$\mathrm{R}_{\mathrm{d}}\left(\mu \mathrm{mol} \mathrm{m} \mathrm{s}^{-1}\right)$ & $3.96 \pm 0.75$ & $2.43 \pm 0.55$ & $1.79 \pm 0.30$ & $0.94 \pm 0.25$ \\
\hline
\end{tabular}

Several models to scale-up carbon assimilation from leaf to canopy level are already in use $[14,16,18]$. After calculating the leaf assimilation rate, we upscaled from leaf- to canopy-level assimilation using LAI as shown in [16]. According to $[16,18]$ the estimation formulas were as follow:

$$
\begin{gathered}
A_{c}=\int_{0}^{h} \int_{0}^{L} A\left(\mathrm{~A}_{\max }, I_{l}\right) d L d t \\
R_{c}=\int_{0}^{n} \int_{0}^{L} R_{d} d L d t
\end{gathered}
$$

Total daily canopy assimilation $\left(\mathrm{A}_{\mathrm{c}}\right)$ can be calculated by considering total leaf area $(\mathrm{L})$, day length (h), and leaf carbon assimilation (A) from Equation (1). Total night canopy respiration $\left(\mathrm{R}_{\mathrm{c}}\right)$ can be calculated by considering total leaf area $(\mathrm{L})$, night length $(n)$, and dark respiration rate $\left(R_{d}\right)$ from light response curves. The differences in mean temperature between day and night in the study period were less than 3 and $4{ }^{\circ} \mathrm{C}$ in winter and 
summer, respectively. Additionally, we calculated monthly assimilation and respiration by considering days in each month, and annual carbon assimilation of $Z$. serrata was calculated by summing up monthly carbon assimilations.

SAS 9.4. statistical software (SAS Inc., Cary, NC, USA) was used to analyze the Pearson correlation between gas exchange and environmental variables. Correlation analysis data were collected from monthly measurement of diurnal variation. Significance was set at $p<0.05$. Data in figures are presented as means \pm standard error.

\section{Results}

In the study area, precipitation from May-September was $94 \%, 92 \%$, and $83 \%$ of the accumulated annual precipitation in 2009, 2010, and 2011, respectively. Soil water content was the lowest in March (8.8\%) and the highest in July (19.4\%) in 2011. Therefore, data from the dry and wet seasons were analyzed separately. The correlations between gas exchange parameters and environmental factors are shown in Table 2. The data showed a significant correlation between $g_{s}$ and $E$ during dry and wet seasons but not between $P_{n}$ and $g_{s}$. The results demonstrated that the leaf transpiration rate was controlled by stomatal closure, but the decrease in $P_{n}$ may be caused by non-stomatal limitation. In both dry and wet seasons, $\mathrm{P}_{\mathrm{n}}$ had no significant correlation with PPFD, but showed significant negative correlations with VPD and temperature in the dry season (Table 2). VPD greatly influenced stomatal opening/closure, especially under dry and high temperature conditions. At the study site, the dry season was over six months and the highest VPD (up to $5.14 \mathrm{kPa}$ ) occurred at noon in March during 2011, demonstrating its impact on plant $\mathrm{CO}_{2}$ assimilation.

Table 2. Correlation coefficients for Zelkova serrata (Thunb.) Makino between gas exchange parameters ( $\mathrm{P}_{\mathrm{n}}$ : net photosynthetic rate, $\mathrm{g}_{\mathrm{s}}$ : stomata conductance, $\mathrm{C}_{\mathrm{i}}$ : intercellular $\mathrm{CO}_{2}$ concentration, $\mathrm{E}$ : transpiration rate) and environmental factors $\left(\mathrm{VPD}_{1}\right.$ : leaf to air vapor pressure deficit, $\mathrm{VPD}_{\mathrm{a}}$ : vapor pressure deficit, $\mathrm{T}_{1}$ : leaf temperature, $\mathrm{T}_{\mathrm{a}}$ : air temperature, $\mathrm{CO}_{2}$ : ambient CO2 concentration, PPFD: photosynthesis photon flux density) in dry (gray) and wet (white) season.

\begin{tabular}{ccccccccccc}
\hline & $\boldsymbol{P}_{\mathbf{n}}$ & $\mathbf{g}_{\mathbf{s}}$ & $\mathrm{C}_{\mathbf{i}}$ & $\mathbf{E}$ & $\mathbf{V P D}_{1}$ & $\mathrm{VPD}_{\mathbf{a}}$ & $\mathrm{T}_{\mathbf{l}}$ & $\mathrm{T}_{\mathbf{a}}$ & $\mathrm{CO}_{2}$ & $\mathbf{P P F D}^{* *}$ \\
\hline$P_{\mathrm{n}}$ & - & 0.14 & $-0.55^{* *}$ & 0.03 & $-0.30^{* *}$ & $-0.33^{* *}$ & $-0.25^{* *}$ & $-0.29^{* *}$ & -0.08 & 0.05 \\
$\mathrm{~g}_{\mathrm{s}}$ & -0.11 & - & $0.34^{* *}$ & $0.81^{* *}$ & $-0.32^{* *}$ & $-0.25^{* *}$ & -0.13 & -0.08 & -0.10 & -0.04 \\
$\mathrm{C}_{\mathrm{i}}$ & $-0.86^{* *}$ & 0.28 & - & $0.26^{* *}$ & -0.14 & -0.05 & 0.00 & 0.09 & 0.15 & $-0.25^{* *}$ \\
$\mathrm{E}$ & 0.22 & $0.77^{* *}$ & 0.02 & - & 0.16 & $0.21^{*}$ & $0.30^{* *}$ & $0.35^{* *}$ & $-0.23^{* *}$ & $0.25^{* *}$ \\
$\mathrm{VPD}_{1}$ & 0.19 & $-0.56^{* *}$ & $-0.36^{*}$ & -0.12 & - & $0.93^{* *}$ & $0.83^{* *}$ & $0.80^{* *}$ & $-0.36^{* *}$ & $0.56^{* *}$ \\
$\mathrm{VPD}_{\mathrm{a}}$ & 0.14 & $-0.50^{* *}$ & $-0.33^{*}$ & -0.18 & $0.87^{* *}$ & - & $0.87^{* *}$ & $0.88^{* *}$ & $-0.35^{* *}$ & $0.43^{* *}$ \\
$\mathrm{~T}_{1}$ & 0.20 & 0.06 & $-0.30^{*}$ & $0.37^{* *}$ & $0.60^{* *}$ & $0.63^{* *}$ & - & $0.96^{* *}$ & $-0.56^{* *}$ & $0.28^{* *}$ \\
$\mathrm{~T}_{\mathrm{a}}$ & 0.15 & 0.12 & -0.26 & $0.39^{* *}$ & $0.51^{* *}$ & $0.60^{* *}$ & $0.97^{* *}$ & - & $-0.48^{* *}$ & $0.26^{* *}$ \\
$\mathrm{CO}_{2}$ & 0.05 & $-0.59^{* *}$ & -0.11 & $-0.56^{* *}$ & $0.35^{*}$ & $0.43^{* *}$ & $-0.29^{*}$ & $-0.32^{*}$ & - \\
$\mathrm{PPFD}^{*}$ & 0.14 & -0.07 & -0.17 & $0.29^{*}$ & $0.61^{* *}$ & $0.32^{*}$ & $0.40^{* *}$ & $0.29^{*}$ & -0.08 & -0.12 \\
\hline
\end{tabular}

$*, * *$ means $p<0.05$ and $p<0.01 . N=138$ (dry season), $N=49$ (wet season).

Diurnal variations in PPFD and VPD on leaves in different seasons are illustrated in Figure 2 and gas exchange variation is shown in Figure 3. Diurnal variations in gas exchange represent the fluctuations in gas exchange during the day and the recovery overnight. The net photosynthesis rate in the four seasons was high in the morning and decreased in the afternoon. In the morning, $P_{n}$ reached 3.8 and $5.6 \mu \mathrm{mol} \mathrm{m}{ }^{-2} \mathrm{~s}^{-1}$ in the dry and wet seasons, respectively. 


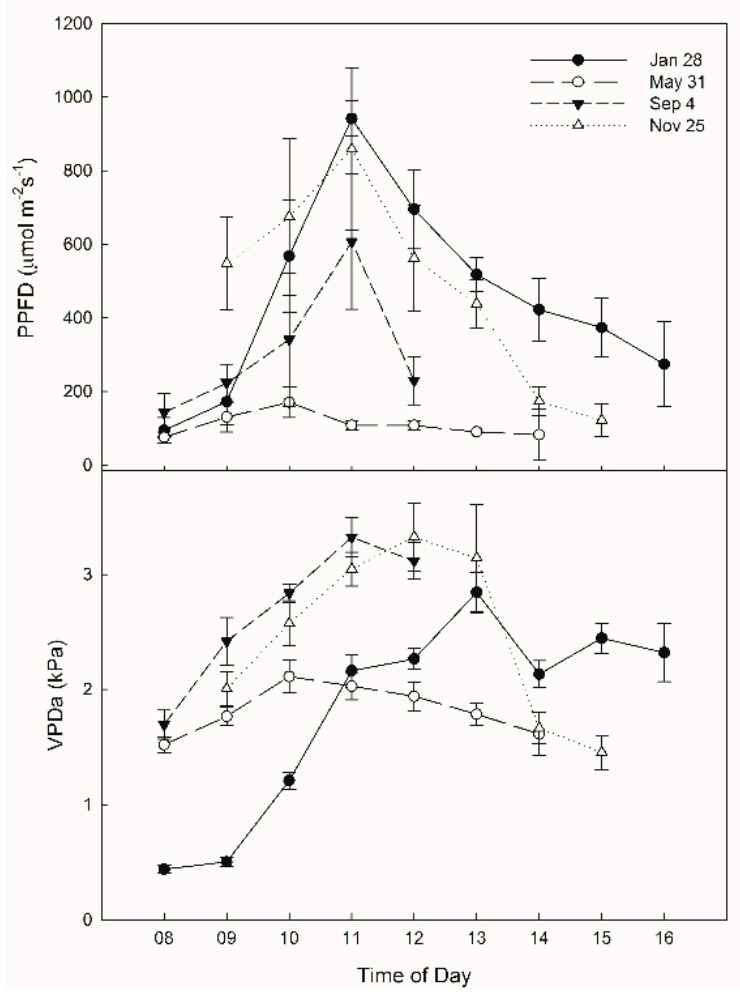

Figure 2. Diurnal variation of light intensity (PPFD) and vapor pressure deficit $\left(\mathrm{VPD}_{\mathrm{a}}\right)$ on 28 January, 31 May, 4 September, and 25 November, 2011. $N=3$, bars indicate \pm standard error.

The daytime $\mathrm{CO}_{2}$ assimilation, nighttime respiration, and LAI are shown in Figure 4 . $\mathrm{CO}_{2}$ assimilation in the wet season was significantly higher than that in the dry season, with the yearly maximum in September $\left(160.9 \mathrm{~g} \mathrm{CO}_{2}\right)$ and the minimum in February $\left(6.7 \mathrm{~g} \mathrm{CO}_{2}\right)$. The daytime carbon sink capacity of trees was lower than the nighttime respiration from January to March. In this study, the single tree nighttime respiration ranged from 14.6 to $85.6 \mathrm{~g} \mathrm{CO}_{2}$. Higher dark respiration and light compensation point values with lower $\mathrm{A}_{\max }$ and light saturation point were observed in the dry season. LAI represented the tree canopy dynamics and frequently fluctuated with seasons. LAI showed high values in spring and summer, thus represented seasonal variation in Z. serrata. However, the experimental area was struck by an intense typhoon in August, causing serious defoliation and low LAI. The difference between the fluctuations in leaf assimilation and monthly $\mathrm{CO}_{2}$ assimilation was mainly caused by the monthly variation in leaf area (Figure 5). The monthly leaf assimilation rate ranged from 0.88 to $4.17 \mu \mathrm{mol} \mathrm{m}^{-2} \mathrm{~s}^{-1}$. The single-tree annual $\mathrm{CO}_{2}$ assimilation was $23.79 \mathrm{~kg}$. Z. serrata carbon assimilation was estimated as $3.50 \mathrm{Mg} \mathrm{C} \mathrm{ha}{ }^{-1}$ year $^{-1}$ in the study area. $\mathrm{CO}_{2}$ assimilation in the dry season was $56 \%$ that of the wet season, mainly caused by higher daytime assimilation and lower nighttime respiration in the wet season than in the dry season (Figure 6). Results also indicated that drought suppressed photosynthesis more than respiration. 


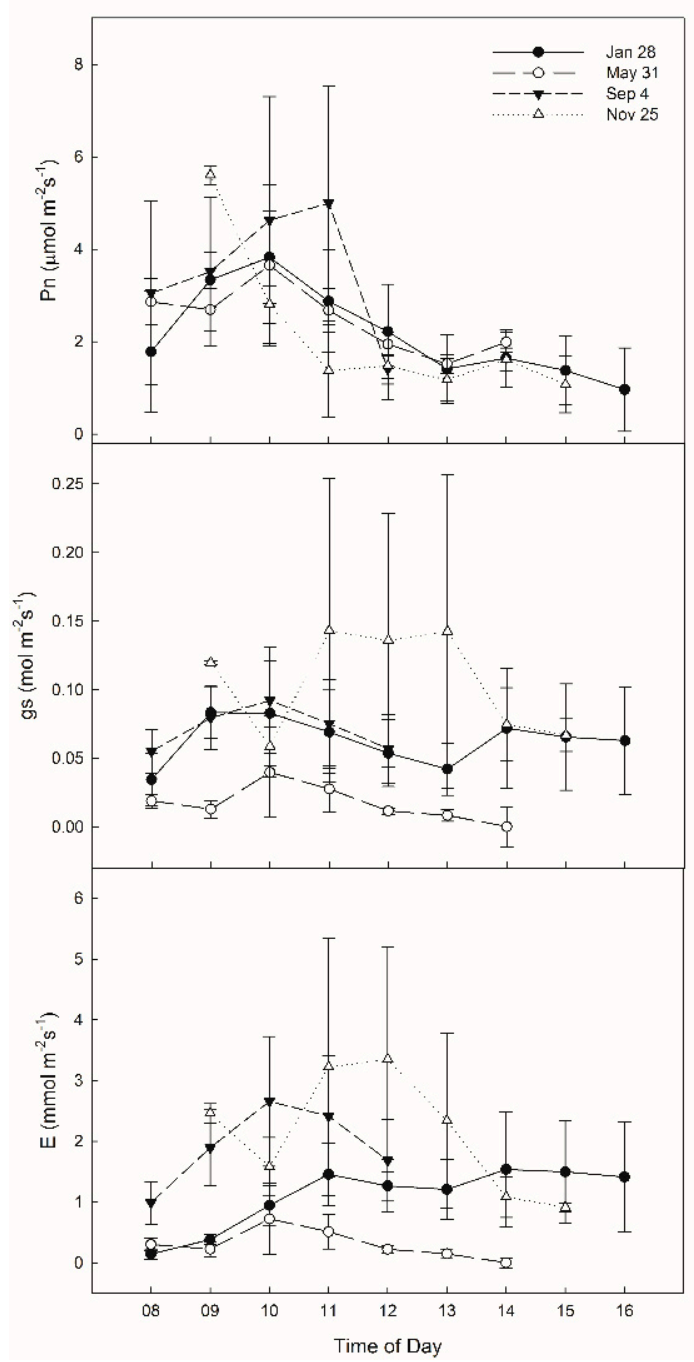

Figure 3. Diurnal variation of net photosynthetic rate $\left(P_{\mathrm{n}}\right)$, stomata conductance $\left(\mathrm{g}_{\mathrm{s}}\right)$, and transpiration rate (E) on 28 January, 31 May, 4 September, and 25 November, 2011. $N=3$, bars indicate \pm standard error.

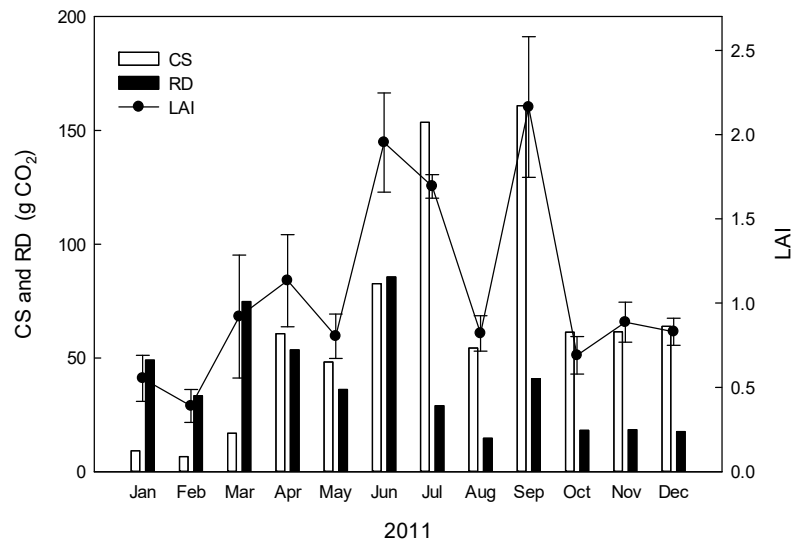

Figure 4. Monthly daytime $\mathrm{CO}_{2}$ assimilation (CS), night respiration (RD), and leaf area index (LAI) of Zelkova serrata (Thunb.) Makino. $N=3$, bars indicate \pm standard error. 


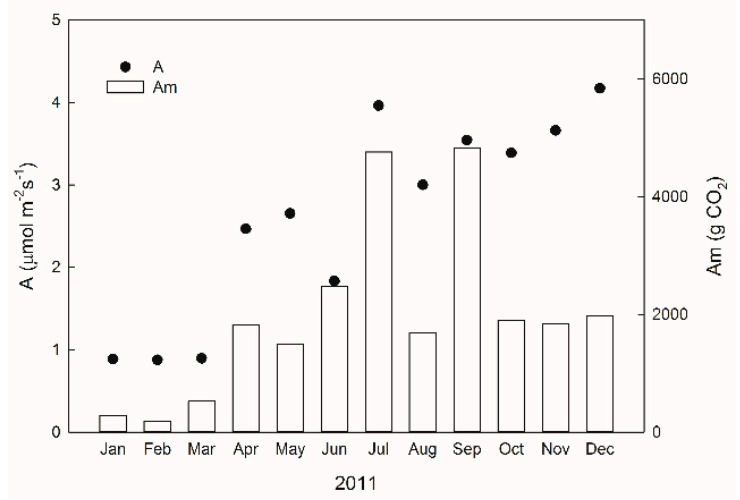

Figure 5. The monthly leaf assimilation rate (A) and monthly $\mathrm{CO}_{2}$ assimilation (Am) of Zelkova serrata (Thunb.) Makino.

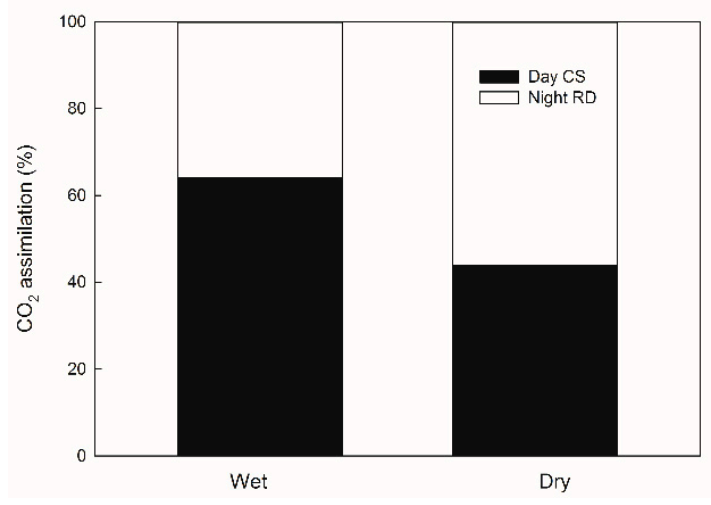

Figure 6. Ratio of day $\mathrm{CO}_{2}$ assimilation (Day $\mathrm{CS}$ ) and night respiration (Night RD) in wet and dry seasons.

\section{Discussion}

\subsection{Gas exchange and Environmental Factors}

The 10-year average annual precipitation was $2700.4 \mathrm{~mm}$ from 2005 to 2014 in southern Taiwan, thus the precipitation in $2011(1929 \mathrm{~mm})$ was much lower than average. The annual evaporation in 2011 (1756.9 mm) was measured by the central weather bureau in southern Taiwan. Plant gas exchange was sensitive to environmental factors such as light intensity, water availability, humidity, and temperature. For example, a water deficit may cause the reduction of stomata conductance, photosynthetic rate, and transpiration, leading to negative effects on plant growth [19-22]. Water deficit is likely to be more severe in the seasonal drought regions; therefore, the selection of plantation species adapted to such environmental stress factors is essential. Different trees species may show different physiological responses to microclimate factors and their interaction in plantation areas. Diurnal variation of gas exchange could be the indicator of maintained photosynthetic capacity in various environmental conditions [23-25].

The diurnal variation of the net photosynthesis rate was high in the morning and decreased in the afternoon. Similar results were found by [26] in young Cinnamomum camphora and Z. serrata in central Taiwan. High values of $\mathrm{P}_{\mathrm{n}}$ in the morning, which decreased after noon without recovery until sunset, were shown occasionally in the field owing to high light intensity, air temperature, and VPD at noon $[27,28]$. The decrease in both $P_{n}$ and $\mathrm{g}_{\mathrm{s}}$ through the day appears to be the result of light-driven accumulations of photosynthesis products [29]. However, the $P_{n}$ values recovered over the following morning, showing that the damage to photosynthesis under environmental stress is transient. We found 
that $g_{s}$ and $E$ showed similar diurnal fluctuation and the values in the wet season were higher than those in the dry season. These results demonstrated that leaf transpiration was controlled by stomatal opening/closure in Z. serrata, as shown in Table 1. Several studies also demonstrated a similar relationship between stomata and water loss during the dry and wet seasons [30,31]. The effects of stomatal or non-stomatal limitation on the reduction of photosynthetic rate can be determined by the correlation between $P_{n}, g_{s}$, and $C_{i}[32,33]$. For example, the positive correlation between $P_{n}$ and $g_{s}$ and the negative correlation between $P_{n}$ and $C_{i}$ were determined as the effect of stomata limitation. Stomata regulation can prevent excess water loss from leaves, but also limit the carbon uptake. The non-significant relation between $P_{n}$ and $g_{s}$ and the significant relation between $g_{s}$ and $E$ demonstrated that the maintenance of leaf water status under drought is more important than carbon uptake [29]. Both temperature and VPD presented a significant correlation with $P_{n}$ in the dry season, showing that the responses of the leaves were directly affected by the high temperature and dry air. Several studies demonstrated that the influence of temperature and VPD on photosynthetic rate was occasionally larger than that of light intensity and soil water content. Thus, the variation of VPD and stomata conductance may influence leaf gas exchange and $\mathrm{CO}_{2}$ assimilation [6,21,34-37]. Harsh environmental conditions could become more severe in the future since climate change could intensify high temperature and drought conditions, causing higher VPD.

Light intensity is one of the key factors influencing photosynthetic rate and, therefore, the forest carbon sink. The optimum range of light intensity is species-specific. However, the photosynthetic light response curve demonstrated the relationship between light intensity and $\mathrm{P}_{\mathrm{n}}$ on leaves and could calculate the light compensation point, $\mathrm{A}_{\max }, \mathrm{R}_{\mathrm{d}}$, and $\alpha[32,38,39]$. These parameters varied both with internal plant factors (e.g., shade tolerance) and external environmental factors (e.g., water stress) [32,40]. In addition, several studies have shown that these parameters can be used to calculate the mean leaf carbon assimilation rate and upscale to the daily carbon assimilation of the whole tree [4,16-18].

\subsection{Leaf Carbon Assimilation and Leaf Area Index}

The mean leaf carbon assimilation rate can be upscaled to the tree and stand level by considering LAI. The results showed that the daytime carbon assimilation was lower than the nighttime respiration in the dry season. Several studies demonstrated that the photosynthetic rate was higher in the wet season than in the dry season $[19,21,22,41]$. Kuo et al. [40] showed that mean light-saturated photosynthetic rate and stomatal conductance measured in the rainy season increased $48 \%$ and $286 \%$, respectively, when compared with the dry season in 30 broad-leaved tree species, demonstrating that stomatal opening was severely restricted during the dry season. Hu et al. [42] showed that the maximum photosynthetic rate may fluctuate 2.2-3.1-fold under different light regimes in subtropical broad-leaved tree species. Moreover, the variation of photosynthetic rate under different environmental conditions also represented the variation of carbon sequestration potential.

A higher $R_{d}$ and light compensation point with lower $A_{\max }$ and light saturation point were observed in the dry season. Generally, the leaf respiration rate is greatly affected by temperature and light intensity and, hence, shows seasonal variation [43]. However, Yin et al. [32] demonstrated that drought impacted the pattern of the photosynthetic light response curve, which increased the dark respiration and light compensation point and decreased $A_{\max }$ and light saturation point. Therefore, the light range utilization was reduced, which decreased the photosynthetic potential. The leaf respiration in the dark is usually higher than in the light, however, the light suppression of respiration may reduce in high temperature conditions [43]. Plant respiration plays an important role in the global carbon cycle, with 120 billion tonnes of carbon sequestered by terrestrial plants compared with 60 billion tonnes of carbon released by plant respiration annually [43]. Additionally, severe drought and increasing temperatures in the future could suppress the photosynthesis and increase respiration in plantations under climate change. 
Total leaf area not only influences the amount of light available but also affects the carbon sequestration of trees because it is the key factor for upscaling from leaf to stand level. High leaf area increases the amount of carbon sequestration by photosynthesis but also increases the amount of carbon emitted by respiration $[44,45]$. The variation of leaf area may be affected by internal factors such as the phenology of each species and external factors such as typhoons and tree pathology [45]. Biswas et al. [16] indicated that the LAI of seven young broadleaf tree species ranged from 1.22 to 3.26 in a plantation area. Chen et al. [46] found that the LAI of Sapindus mukorossi in the plain area ranged from 0.75 to 3.74. Compared with previous studies, the lower LAI (0.39-2.16) in Z. serrata at the study site may be caused by poor site quality, specific difference, and plant pathology $[47,48]$.

\subsection{Seasonal Carbon Assimilation}

The leaf assimilation rate can be upscaled to single-tree monthly $\mathrm{CO}_{2}$ assimilation by considering total leaf area and day length (Figure 5). The monthly leaf assimilation rate in Z. serrata was lower than that of S. mukorossi $\left(1.18-9.10 \mu \mathrm{mol} \mathrm{m}^{-2} \mathrm{~s}^{-1}\right)$ in Southern Taiwan [46] and seven broad-leaved tree species (1.37-11.61 $\left.\mu \mathrm{mol} \mathrm{m}^{-2} \mathrm{~s}^{-1}\right)$ in Eastern India [16]. However, a previous study demonstrated that the poor site quality in the study area may be caused by a long-term monoculture of sugarcane [12]. In addition, many trees showed symptoms of sooty mold in this area. Therefore, the effects of pathology on leaf photosynthesis could be an interesting field of research.

The single-tree annual $\mathrm{CO}_{2}$ assimilation rates were lower than those of other studies in Taiwan such as $96.14 \mathrm{~kg} \mathrm{CO}_{2}$ year $^{-1}$ in Z. serrata [26], $100 \mathrm{~kg} \mathrm{CO}_{2}$ year $^{-1}$ in Phyllostachys pubescens [49], $230 \mathrm{~kg} \mathrm{CO}_{2}$ year $^{-1}$ in Cinnamomum camphora [50], and $56.8 \mathrm{~kg} \mathrm{CO}_{2} \mathrm{year}^{-1}$ in Alstonia scholaris [51]. However, several studies showed similar $\mathrm{CO}_{2}$ assimilation to that of Z. serrata, such as $18.0 \mathrm{~kg} \mathrm{CO}_{2}$ year $^{-1}$ in Pongamia pinnata [52] and $19.1 \mathrm{~kg} \mathrm{CO}_{2} \mathrm{year}^{-1}$ in Pte- $^{-}$ rocarpus indicus [17]. The estimation methods of $\mathrm{CO}_{2}$ assimilation in the studies mentioned above were also based on photosynthesis. The difference of annual $\mathrm{CO}_{2}$ assimilation may be affected by interspecific differences, regional climate, and seasonal climatic shifts [53-55]. Our study found a lower amount of $\mathrm{CO}_{2}$ assimilation ( $23.79 \mathrm{~kg}_{\text {tree }}^{-1}$ year $^{-1}$ ) than another study (96.14 kg tree tear $^{-1}$ ) [26] conducted in secondary forest in central Taiwan. The difference may be caused by the poor site quality, including shallow soils, high gravel content, long-term tillage, and prolonged drought in our study site. Plantations in shallow and rocky soils may have a lower growth rate and carbon accumulation potential. For example, the aboveground biomass of $Z$. serrata in deep and shallow soils was $32 \mathrm{Mg} \mathrm{C} \mathrm{ha-1}$ and $9 \mathrm{Mg} \mathrm{C} \mathrm{ha-1,} \mathrm{respectively} \mathrm{[48].}$

The balance between $\mathrm{CO}_{2}$ sink and source during drought is important because future drought in tropical regions may increase in frequency and severity because of global climate change [55]. These adverse weather conditions cause a reduction in tree growth, showing the serious impact of such climate extremes on carbon sequestration in dry tropical forest ecosystems [56]. Collectively, the results of the present study offer insights on photosynthesis and carbon assimilation dynamics in Z. serrata plantations, which could facilitate the assessment and management of plantation species under projected climate change.

\section{Conclusions}

Forests play a crucial role in terrestrial carbon budgets under climate change and provide several important ecosystem service functions. Extreme weather events such as prolonged drought and high temperature strongly impact the growth and carbon sink capacity of plantations. High VPD and high temperature conditions considerably influence the net photosynthesis rate of $Z$. serrata plantations in the dry season. However, the gas exchange rate recovered over the following morning, showing that the environmental stresses may not permanently suppress carbon assimilation by plantations. The environmental stress factors that are prominent during the dry season suppressed carbon assimilation 
by $43 \%$. Additionally, the relatively low carbon assimilation by Z. serrata plantation at the study site could be attributed to poor site quality.

Author Contributions: C.-I.C., Y.-C.C. and Y.-N.W. conceived of the study, and participated in its design and coordination, and helped to draft the manuscript. C.-I.C., H.-H.L. and J.-C.Y. collected, analyzed, and interpreted data. C.-I.C. and C.-W.W. wrote the manuscript. C.-W.W. and Y.-N.W. advised throughout. All authors have read and agreed to the published version of the manuscript.

Funding: This research received no external funding.

Acknowledgments: We thank the researchers at the Experimental Forest, National Taiwan University, for their help with data collection and field measurements. We also express our gratitude to the members of the Silviculture Laboratory, School of Forestry and Resource Conservation, National Taiwan University, for their assistance and cooperation.

Conflicts of Interest: The authors declare no conflict of interest.

\section{References}

1. Lee, K.J.; Lin, J.C.; Lain, C.S.; Lin, L.C. Carbon sequestration effects in different forest ecosystem management scenario in experimental forest, National Taiwan University. J. Exp. For. Nat. Taiwan Univ. 2004, 18, 261-272.

2. Solomon, N.; Birhane, E.; Tadesse, T.; Treydte, A.C.; Meles, K. Carbon stocks and sequestration potential of dry forests under community management in Tigray, Ethiopia. Ecol. Process 2017, 6, 20. [CrossRef]

3. Chen, C.I.; Wang, Y.N.; Lih, H.W.; Yu, J.C. Three-year study on diurnal and seasonal $\mathrm{CO}_{2}$ sequestration of a young Fraxinus griffithii plantation in southern Taiwan. Forests 2016, 7, 230. [CrossRef]

4. Lin, J.C.; Jeng, M.R.; Liu, S.F; Lee, L.J. Economic benefit evaluation of the potential $\mathrm{CO}_{2}$ sequestration by the national reforestation program. Taiwan J. For. Sci. 2002, 17, 311-321.

5. Dai, Z.; Johnson, K.D.; Birdsey, R.A.; Hernandez-Stefanoni, J.L.; Dupuy, J.M. Assessing the effect of climate change on carbon sequestration in a Mexican dry forest in the Yucatan Peninsula. Ecol. Complex. 2015, 24, 46-56. [CrossRef]

6. Sulman, B.N.; Roman, D.T.; Yi, K.; Wang, L.; Phillips, R.P.; Novick, K.A. High atmospheric demand for water can limit forest carbon uptake and transpiration as severely as dry soil. Geophys. Res. Lett. 2016, 43, 9686-9695. [CrossRef]

7. Wehr, R.; Munger, J.W.; McManus, J.B.; Nelson, D.D.; Zahniser, M.S.; Davidson, E.A.; Wofsy, S.C.; Saleska, S.R. Seasonality of temperate forest photosynthesis and daytime respiration. Nature 2016, 534, 680-683. [CrossRef] [PubMed]

8. Albert, L.P.; Wu, J.; Prohaska, N.; de Camargo, P.B.; Huxman, T.E.; Tribuzy, E.S.; Ivanov, V.Y.; Oliveira, R.S.; Garcia, S.; Smith, M.N.; et al. Age-dependent leaf physiology and consequences for crown-scale carbon uptake during the dry season in an Amazon evergreen forest. New Phytol. 2018, 219, 870-884. [CrossRef]

9. Flanagan, P.X.; Basara, J.B.; Illston, B.G.; Otkin, J.A. The effect of the dry line and convective initiation on drought evolution over Oklahoma during the 2011 drought. Adv. Meteorol. 2017, 2017. [CrossRef]

10. Doughty, C.E.; Metcalfe, D.B.; Girardin, C.A.J.; Amézquita, F.F.; Cabrera, D.G.; Huasco, W.H.; Silva-Espejo, J.E.; Araujo-Murakami, A.; da Costa, M.C.; Rocha, W.; et al. Drought impact on forest carbon dynamics and fluxes in Amazonia. Nature 2015, 519, 78-82. [CrossRef]

11. Cao, C.; Tao, J. Predicting the areas of suitable distribution for Zelkova serrata in China under climate change. Sustainability 2021, 13, 1493. [CrossRef]

12. Chen, C.I.; Wang, Y.N.; Yeh, L.W.; Hsieh, C.Y.; Yu, J.C.; Wu, C.S. Assessment of growth and $\mathrm{CO}_{2}$ sequestration of Zelkova serrata in the Wan-Long farm, Pingdong. J. Exp. For. Nat. Taiwan Univ. 2012, 26, 191-199.

13. Yu, J.C.; Chen, C.I.; Chiang, P.N.; Lai, Y.J.; Tsai, M.J.; Wang, Y.N. Preliminary study of $\mathrm{CO}_{2}$ flux in Pingdong plantations. J. Exp. For. Nat. Taiwan Univ. 2012, 26, 163-174.

14. Thornley, J.H.M. Instantaneous canopy photosynthesis: Analytical expressions for sun and shade leaves based on exponential light decay down the canopy and an acclimated non-rectangular hyperbola for leaf photosynthesis. Ann. Bot. 2002, 89, 451-458. [CrossRef]

15. Lambers, H.; Chapin, F.S., III; Pons, T.L. Plant Physiological Ecology; Springer: New York, NY, USA, 1998.

16. Biswas, S.; Bala, S.; Mazumdar, A. Diurnal and seasonal carbon sequestration potential of seven broadleaved species in a mixed deciduous forest in India. Atmos. Environ. 2014, 89, 827-834. [CrossRef]

17. Chen, C.I.; Wang, Y.N.; Yu, J.C. Diurnal and seasonal $\mathrm{CO}_{2}$ assimilation by four plantation species in Taiwan. For. Sci. 2019, 65, $68-76$. [CrossRef]

18. Sands, P.J. Modeling canopy production. II. From single-leaf photosynthetic parameters to daily canopy photosynthesis. Funct. Plant Biol. 1995, 22, 603-614. [CrossRef]

19. Colom, M.R.; Vazzana, C. Photosynthesis and PSII functionality of drought-resistant and drought-sensitive weeping lovegrass plant. Environ. Exp. Bot. 2003, 49, 135-144. [CrossRef]

20. Grzesiak, M.T.; Grzesiak, S.; Skoczowski, A. Changes of leaf water potential and gas exchange during and after drought in triticale and maize genotypes differing in drought tolerance. Photosynthetica 2006, 44, 561-568. [CrossRef] 
21. Li, X.W.; Chen, S.L. Diurnal changes in gas exchange and chlorophyll fluorescence parameters of Fritillaria cirrhosa and F. delavayi under field conditions. Photosynthetica 2009, 47, 191-198. [CrossRef]

22. Ogaya, R.; Peñuelas, J. Comparative field study of Quercus ilex and Phillyrea latifolia: Photosynthetic response to experimental drought conditions. Environ. Exp. Bot. 2003, 50, 137-148. [CrossRef]

23. Ding, L.; Wang, K.J.; Jiang, G.M.; Li, Y.G.; Jiang, C.D.; Liu, M.Z.; Niu, S.L.; Peng, Y. Diurnal variation of gas exchange, chlorophyll fluorescence, and xanthophyll cycle components of maize hybrids released in different years. Photosynthetica 2006, 44, 26-31. [CrossRef]

24. Jhou, H.C.; Wang, Y.N.; Wu, C.S.; Yu, J.C.; Chen, C.I. Photosynthetic gas exchange response of Swietenia macrophylla King and Melia azedarach L. plantations under drought conditions. Bot. Stud. 2017, 58, 57. [CrossRef] [PubMed]

25. Ngugi, M.R.; Doley, D.; Hunt, M.A.; Dart, P.; Ryan, P. Leaf water relations of Eucalyptus cloeziana and E. argophloia in response to water deficit. Trees 2004, 23, 335-343. [CrossRef]

26. Liao, S.H.; Wang, Y.N. Study on carbon dioxide fixation efficiency of Cinnamomum camphora and Zelkova serrata in understory planting. Q. J. Chin. For. 2002, 35, 361-373.

27. Gao, Z.J.; Xu, B.C.; Wang, J.; Huo, L.J.; Li, S. Diurnal and seasonal variations in photosynthetic characteristics of switchgrass in semiarid region on the Loess Plateau of China. Photosynthetica 2015, 53, 489-498. [CrossRef]

28. Hamada, S.; Kumagai, T.; Kochi, K.; Kobayashi, N.; Hiyama, T.; Miyazawa, Y. Spatial and temporal variations in photosynthetic capacity of a temperate deciduous-evergreen forest. Trees 2016, 30, 1083-1093. [CrossRef]

29. Matthews, J.S.A.; Vialet-Chabrand, S.R.M.; Lawson, T. Diurnal variation in gas exchange: The balance between carbon fixation and water loss. Plant Physiol. 2017, 174, 614-623. [CrossRef] [PubMed]

30. Arndt, S.K.; Sanders, G.J.; Bristow, M.; Hutley, L.B.; Beringer, J.; Livesley, S.J. Vulnerability of native savanna trees and exotic Khaya senegalensis to seasonal drought. Tree Physiol. 2015, 35, 783-791. [CrossRef]

31. Li, S.; Feifel, M.; Karimi, Z.; Schuldt, B.; Choat, B.; Jansen, S. Leaf gas exchange performance and the lethal water potential of five European species during drought. Tree Physiol. 2016, 36, 179-192. [CrossRef]

32. Yin, C.Y.; Berninger, F.; Li, C.Y. Photosynthetic responses of Populus przewalski subjected to drought stress. Photosynthetica 2006, 44, 62-68. [CrossRef]

33. Zhang, X.H.; Lang, D.Y.; Zhang, E.H.; Bai, C.C.; Wang, H.Z. Diurnal changes in photosynthesis and antioxidants of Angelica sinensis as influenced by cropping systems. Photosynthetica 2013, 51, 252-258. [CrossRef]

34. Cordeiro, Y.E.M.; Pinheiro, H.A.; Santos Filho, B.G.; Corrêa, S.S.; Silva, J.R.R.; Dias-Filho, M.B. Physiological and morphological responses of young mahogany (Swietenia macrophylla King) plants to drought. For. Ecol. Manag. 2009, 258, 1449-1455. [CrossRef]

35. Koch, G.W.; Amthor, J.S.; Goulden, M.L. Diurnal patterns of leaf photosynthesis, conductance and water potential at the top of a lowland rain forest canopy in Cameroon: Measurements from the Radeau des Cimes. Tree Physiol. 1994, 14, 347-360. [CrossRef] [PubMed]

36. Slot, M.; Winter, K. In situ temperature response of photosynthesis of 42 tree and liana species in the canopy of two Panamanian lowland tropical forests with contrasting rainfall regimes. New Phytol. 2017, 214, 1103-1117. [CrossRef] [PubMed]

37. Tucci, M.L.S.; Erismann, N.M.; Machado, E.C.; Ribeiro, R.V. Diurnal and seasonal variation in photosynthesis of peach palms grown under subtropical conditions. Photosynthetica 2010, 48, 421-429. [CrossRef]

38. Lachapelle, P.P.; Shipley, B. Interspecific prediction of photosynthetic light response curves using specific leaf mass and leaf nitrogen content: Effects of differences in soil fertility and growth irradiance. Ann. Bot. 2012, 109, 1149-1157. [CrossRef]

39. Lang, Y.; Wang, M.; Zhang, G.C.; Zhao, Q.C. Experimental and simulated light responses of photosynthesis in leaves of three tree species under different soil water conditions. Photosynthetica 2013, 51, 370-378. [CrossRef]

40. Kuo, Y.L.; Fan, K.S.; Hwang, C.W.; Lee, Y.P.; Wu, H.L.; Tsai, R.F. Gas exchange potential in sun-exposed leaves of 30 broadleaf tree species in Taiwan. Taiwan J. For. Sci. 2004, 19, 375-386.

41. Bucher, S.F.; Bernhardt-Römermann, M.; Römermann, C. Chlorophyll fluorescence and gas exchange measurements in field research: An ecological case study. Photosynthetica 2018, 56, 1161-1170. [CrossRef]

42. Hu, Q.P.; Guo, Z.H.; Li, C.Y.; Ma, L.Y. Leaf morphology and photosynthetic characteristics of seedlings of a deciduous and an evergreen broad-leaved species under different light regimes in subtropical forests. Acta Ecol. Sin. 2008, 28, 3262-3270.

43. Way, D.A.; Holly, C.; Bruhn, D.; Ball, M.C.; Atkin, O.K. Diurnal and seasonal variation in light and dark respiration in field-grown Eucalyptus pauciflora. Tree Physiol. 2015, 35, 840-849. [CrossRef] [PubMed]

44. Bonan, G.B. Importance of leaf area index and forest type when estimating photosynthesis in boreal forests. Remote Sens. Environ. 1993, 43, 303-314. [CrossRef]

45. Gond, V.; de Pury, D.G.G.; Veroustraete, F.; Ceulemans, R. Seasonal variations in leaf area index, leaf chlorophyll, and water content; scaling-up to estimate fAPAR and carbon balance in a multispecies temperate forest. Tree Physiol. 1999, 19, 673-679. [CrossRef] [PubMed]

46. Chen, C.I.; Lih, X.W.; Yu, J.C.; Wang, Y.N. The carbon sequestration potential of Sapindus Mukorossi in the Wan-Long farm, Pingtung. J. Exp. For. Nat. Taiwan Univ. 2016, 30, 119-126.

47. Yeh, H.T.; Lee, C.F.; Wu, S.; Shih, L.C.; Wang, Y.N.; Yu, J.C. Investigation of insect feeding guilds on Zelkova Serrata (Ulmaceae) in Wanlong plantation, Pintung county. J. Exp.For. Nat. Taiwan Univ. 2013, 27, 251-262.

48. Cheng, C.H.; Huang, Y.H.; Menyailo, O.V.; Chen, C.T. Stand development and aboveground biomass carbon accumulation with cropland afforestation in Taiwan. Taiwan J. For. Sci. 2016, 31, 105-118. 
49. Tu, T.C.; Wang, Y.N.; Shiau, E.L. Efficiency of carbon dioxide fixation by Phyllostachys pubescens. J. Exp. For. Nat. Taiwan Univ. 2003, 17, 187-194.

50. Hong, L.W.; Wang, Y.N. Net photosynthetic productivity at different canopy layers of Cinnamomum camphora. Q. J. Chin. For. 2003, 36, 27-38.

51. Wang, Y.N.; Liou, S.C.; Shiau, I.L. The carbon dioxide fixation efficiency of Alstonia scholaris of sidewalk tree. Q. J. Chin. For. 2005, 38, 279-290.

52. Wang, Y.N.; Liou, S.C.; Shiau, I.L. The carbon dioxide fixation efficiency of Pongamia pinnata of sidewalk tree. Q. J. Chin. For. 2005, 38, 151-161.

53. Barford, C.C.; Wofsy, S.C.; Goulden, M.L.; Munger, J.W.; Pyle, E.H.; Urbanski, S.P.; Hutyra, L.; Saleska, S.R.; Fitzjarrald, D.; Moore, L. Factors controlling long- and short-term sequestration of atmospheric $\mathrm{CO}_{2}$ in a mid-latitude forest. Science 2001, $294,1688$. [CrossRef] [PubMed]

54. Goulden, M.L.; McMillan, A.M.S.; Winston, G.C.; Rocha, A.V.; Manies, K.L.; Harden, J.W.; Bond-Lamberty, B.P. Patterns of NPP, GPP, respiration, and NEP during boreal forest succession. Glob. Chang. Biol. 2011, 17, 855-871. [CrossRef]

55. Grünzweig, J.M.; Lin, T.; Rotenberg, E.; Schwartz, A.; Yakir, D. Carbon sequestration in arid-land forest. Glob. Chang. Biol. 2003, 9 , 791-799. [CrossRef]

56. Spannl, S.; Volland, F.; Pucha, D.; Peters, T.; Cueva, E.; Bräuning, A. Climate variability, tree increment patterns and ENSO-related carbon sequestration reduction of the tropical dry forest species Loxopterygium huasango of Southern Ecuador. Trees 2016, 30, 1245-1258. [CrossRef] 